Millatī, Journal of Islamic Studies and Humanities

Vol. 5, No. 1, June 2020: p. 81-97. DOI: 10.18326/mlt.v5i1. 81-97

p-ISSN : 2541-3627 ; e-ISSN 2540-9964

Website: http://millati.iainsalatiga.ac.id/index.php/millati/index

\title{
Problematic of Katoba Tradition : Study of Islamic Rituals in Muna Communities
}

\author{
Aida Hayani \\ UIN Sunan Kalijaga Yogyakarta, Indonesia \\ aidaalmabira@yahoo.com
}

\author{
Aris Armeth Daud Al Kahar \\ LAIN Kendari, Indonesia \\ arisarmeth@yahoo.com
}

\begin{abstract}
This article discusses the katoba ritual in Muna. This study aims to uncover the symbols in ritual, as well as knowing the dynamic changes that occurred in the katoba ritual community tradition. This type of research is a qualitative descriptive study by collecting data through interviews, observations, and documentation. The data were analyzed by using data reduction, display, and verification techniques. Victor Turner's symbol theory was used to analyze the symbolic meaning contained in the katoba ritual. The theory of change dynamics was used to look at the problems arisen in the katoba ritual in the contemporary era. The results showed that there was a meaning in the ritual of the katoba. The meaning was derived from the symbolic articles (materialistic aspects of the ritual of the katoba) and the symbolic actions (non-object aspects) at each stage. The dynamic changes that occurred in Muna society affected the implementation of the katoba ritual. The presence of formal educational institutions was able to shift or replace the role of the katoba ritual in the middle of the Muna community.
\end{abstract}

Keywords: Tradition, Katoba, Muna Community

\begin{abstract}
Artikel ini membahas ritual katoba di Muna. Penelitian ini bertujuan untuk mengungkap simbol-simbol dalam ritual, serta mengetahui perubahan dinamis yang terjadi dalam tradisi komunitas ritual katoba di Muna. Jenis penlitian ini merupakan penelitian deskriptif kualitatif dengan mengumpulkan data melalui wawancara, observasi, dan dokumentasi. Analisis data menggunakan teknik reduksi, tampilan, dan verifikasi data. Teori simbol Victor Turner digunakan untuk menganalisis makna simbolik yang terkandung dalam ritual katoba. Selain itu, teori dinamika perubahan dapat digunakan untuk melihat permasalahan-permasalahan yang muncul dalam ritual katoba di era kontemporer. Hasil penelitian menunjukkan bahwa terdapat makna dalam ritual katoba.. Makna tersebut berasal dari artikel simbolik (aspek materialistis dari ritual katoba) dan aksi simbolik (aspek non-objek) di setiap tahapannya. Perubahan dinamis yang terjadi di masyarakat Muna berpengaruh terhadap pelaksanaan ritual katoba. Selain itu, kehadiran lembaga pendidikan formal ternyata mampu menggeser atau menggantikan peran ritual katoba di tengah-tengah masyarakat Muna.
\end{abstract}

Kata kunci: Tradisi, Katoba, Masyarakat Muna 
Millatī, Journal of Islamic Studies and Humanities, Vol. 5, No. 1, June 2020: 81-97

\section{INTRODUCTION}

At the ceremony, there Muna public life cycle in the life of the individual, starting from birth up until the ceremony funeral ceremonies. To carry out the ceremony, an individual must go through several stages. One such step is childhood, especially males, and there is a ceremony which they call katoba ceremony. Culture is a unit of human history itself that is the human being and the human individual as a social being at the same time tying the actual content is not free from logical and social consequences as well. ${ }^{1}$ In line with the opinions, Koenjaraningrat argued that indigenous communities shared the individual's life through certain levels, which in Anthropology called "Stages the Along Live Cycle" is the transition from infancy, childhood, adolescence, puberty, years after marriage, pregnancy until delivery, until old age. ${ }^{2}$

Toba in society can mean holy Muna, which means returning to a state of purity something or make something sacred. Katoba's own words can mean sanctification. A child who is 'in-katoba' means the child back into a state of purity, to be a true Muslim. In ancient times, children who are 'in-katoba' are not allowed to touch Qur'an, entered the mosque, or establish prayer because the child is not sacred. However, this time a child, although not 'inkatoba,' has been able to learn to read the Qur'an, learning prayers, fasting, and others. Katoba tradition is a tradition that is appreciated by the public Muna expressive language as a medium of education and value-laden character.

There are three fundamental things as the reason for the implementation of this study. The first reason is the tradition of the procession katoba is very important for the community because this is where the provision of education Muna child wrapped in a tradition. The second reason is the era of globalization, the flow of modernity increasingly rampant tradition katoba still awake neat and reliable, given many moral messages contained in the oral tradition. The third reason is essentially through culture reflected educational values that can be learned and can prove the greatness of the culture of the disclosure of the meaning of the symbols used in the katoba ritual. The reasons for performing searches spur academic writers with scientific methods, supported by strengthening the theoretical basis.

\footnotetext{
1 Alimin Malonda, Nilai Pendidikan dan Nilai Moral dalam Falia dalam Masyarakat Muna di Kecamatan Parigi Kabupaten Muna, (Kendari: FKIP, 2011): p. 12.

${ }^{2}$ Koentjaraningrat, Beberapa Pokok Antropologi Sosial, (Jakarta: DIAN People, 1992): p 92.
} 


\section{METHODS}

Katoba tradition is a ritual performed by Muna society. Ritual is a process of interaction that is not static and contain moral messages in its communication. Katoba ritual is a cultural product that can not be separated from the various symbols attached to it. The existence of this ritual is a form of religion or religious symbols and symbolism of human culture. Symbolic action in a religious ceremony is an essential part. Katoba ritual is a tradition that terms of the signs and symbols and language. These symbols have significance for the people of Muna. To analyze the meaning of these symbols, Peirce theorized triangle or triangle meaning that consists of three main elements, namely a sign (sign), object, and interpretant. Signs are physical objects that can be captured by the five human senses and is something that refers to (represent) something other than the sign itself. Peirce mark consists of a symbol (the marking of the deal), icon (mark that appears on the physical representation), and index (the marking of causeeffect relationships). At the same time, this sign is called an object reference. ${ }^{3}$

Therefore it is a necessary livelihood in-depth with scientific methods and theories that support it. Two blades used in analyzing the katoba ritual are first, semiotic theory examining the symbols and language or expressions contained in the ritualistic katoba. The analysis will produce meanings embodied in symbols and expressions katoba, and the second is the theory of cultural change to assess dynamics and problems that occur in ritual katoba. To illustrate the use of theory in this study, the authors make a theoretical chart as illustrated below:

\section{Framework Research}

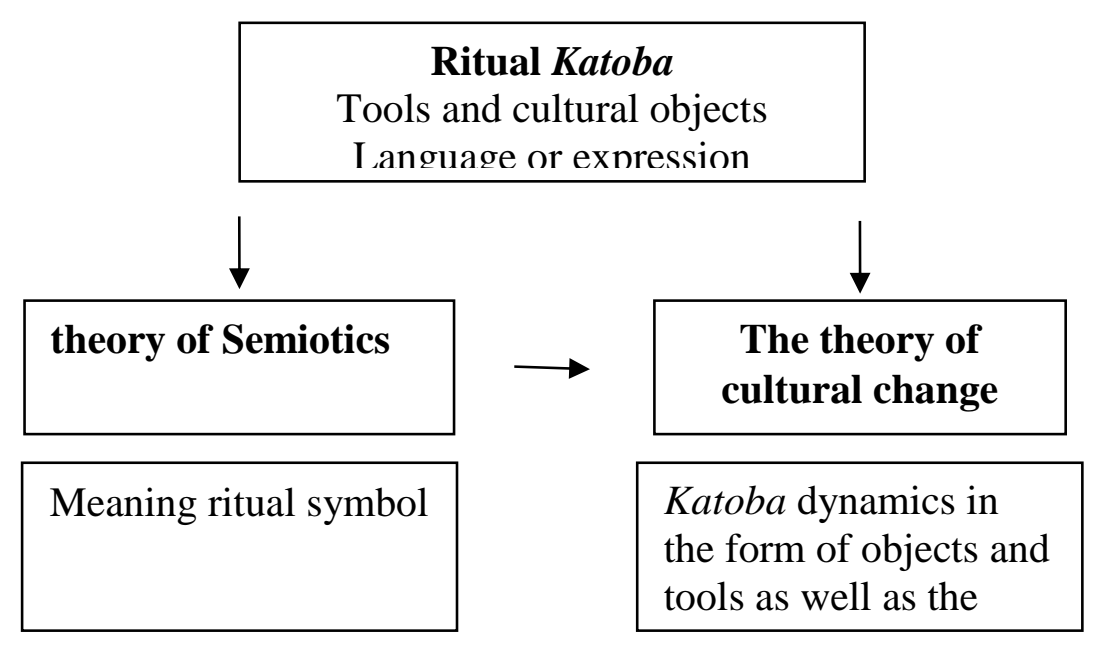

3 Stephan W. Littlejohn dan Karen A. Foss, Teori Komunikasi, Ed. 9, Translated by Muhammad Yusuf Hamdan, (Jakarta: Salemba Humanika, 2009) 
Millatī, Journal of Islamic Studies and Humanities, Vol. 5, No. 1, June 2020: 81-97

Research is a process of data collection, and analysis carried out systematically and logically to achieve specific goals. ${ }^{4}$ The research method is a scientific way to get data with purpose and usefulness. ${ }^{5}$ This research method is a plan to solve research problems. The type used in this research is a qualitative method directly related to the collection and analysis of data in the research report. This method aims to explain the systematic, factual, and accurate through observations realized through words or sentences.

The data in this study was the observation in a ceremonial procession Katoba recorded directly as well as interviews with informants traditional leaders who become informants in this study. In this study, sources of data are a group of people who hold process Katoba as well as knowing the procession Katoba itself, in this case, the community leaders and traditional leaders in these community leaders and traditional authorities, Mr. La Ode Baaru and Mr. La Maruhi. The data were analyzed by descriptive qualitative, then described in the form of words or phrases to find their elements. The stages are transcripts of recorded data, which is to transfer data into the actual writing. Classification of data, gathering all the data corresponding to the shape of the character, is eligible. Translation of data, which translates all collected data into Indonesian. The description, which the researchers describe the overall values are in a ceremonial procession katoba. Analysis of the data, the researchers analyzed all the data collected in the form of writing and recording based on its meaning.

\section{DISCUSSION}

Muna is one of the regencies located in Southeast Sulawesi and inaugurated as a district in 1960. Previously, Muna town located about 25 kilometers from Raha, Muna capital city now. People call Wuna Muna, Muna rate as the original name, and also the island of Muna. However, the word "Wuna" had been pronounced and finally written into "Muna" in reports and official languages. Tamburaka explains when the Dutch arrived in Muna and infuse power in 1906, the term Wuna replaced with "Muna" tailored to the greeting or the tongue of the Netherlands (the consonant "W" to "M"). Since then. The term "Muna" became well-known and commonly used by the public, especially foreigners, or those outside the area Muna, but

\footnotetext{
${ }^{4}$ Sukmadinata dan Nana Syaodih, Metode Penelitian Pendidikan, (Yogyakarta: Kurnia Kalam Universe, 2003): p. 51.

${ }^{5}$ Sugiyono, Metode Penelitian Kualitatif Kuantitatif R \& D (Bandung: Alfabeta, 2011): p. 2.
} 
the Beraama Muna tribe majority of Islam. ${ }^{6}$ The trust factor and religious beliefs espoused the community, serves to instill the values and norms of sacredness or sanctity of the concept of the teachings contained in the form of cultural traditions. In contrast, the legalization factor of power and government systems kingdom/sultanate in the past serves to instill the values and norms of coercive power against a form of cultural traditions and then function as an amplifier and an escort in the process of developing conceptual. The development of basic concepts and the development of cultural traditions from generation to generation in traditional societies in the past have two dominant factors: the factors of trust and confidence of religious communities. ${ }^{7}$

\section{The Process of Institutionalization of Muna Cultural Traditions}

The process institutionalization of Muna cultural traditions is described as follows. ${ }^{8}$

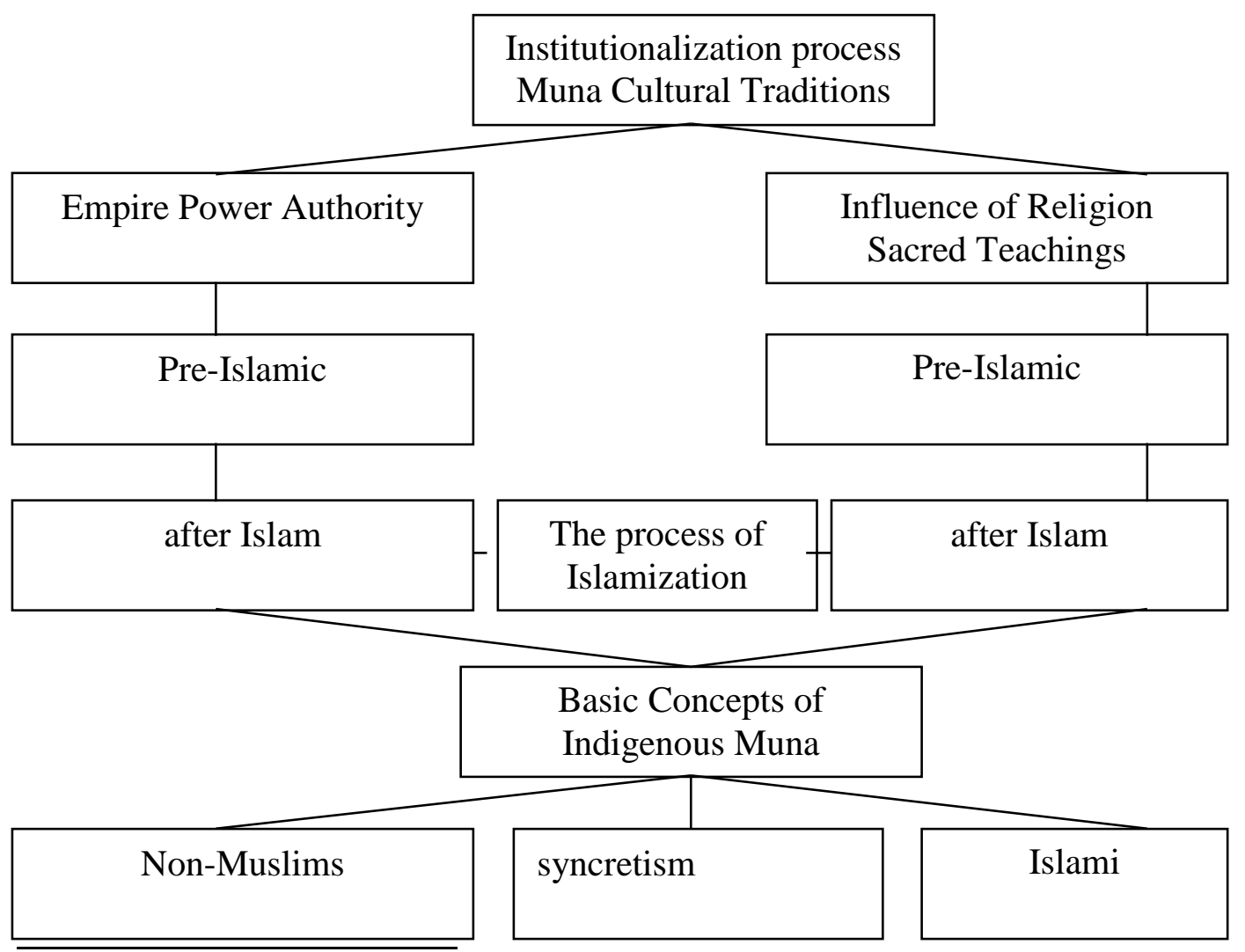

${ }^{6}$ Tamburaka, Sejarah Sulawesi Tenggara dan 40 Tahun Sultra Membangun, (Kendari: Southeast Sulawesi Provincial Government., 2004): p. 371

7 Hadirman, "Sejarah dan Bahasa Figuratif dalam Tradisi Katoba pada Masyarakat Muna", Journal AQL AM, (IAIN Manado, Vol. 2, No. 01, 2017): p. 50.

${ }^{8}$ Lutfi Muh. Malik, Islam dalam Budaya Muna: Suatu Ikhtiar Menatap Masa Depan, (Ujung Pandang: PT Umitoha Ukhuwwat Graphic, 1997): p. 13. 


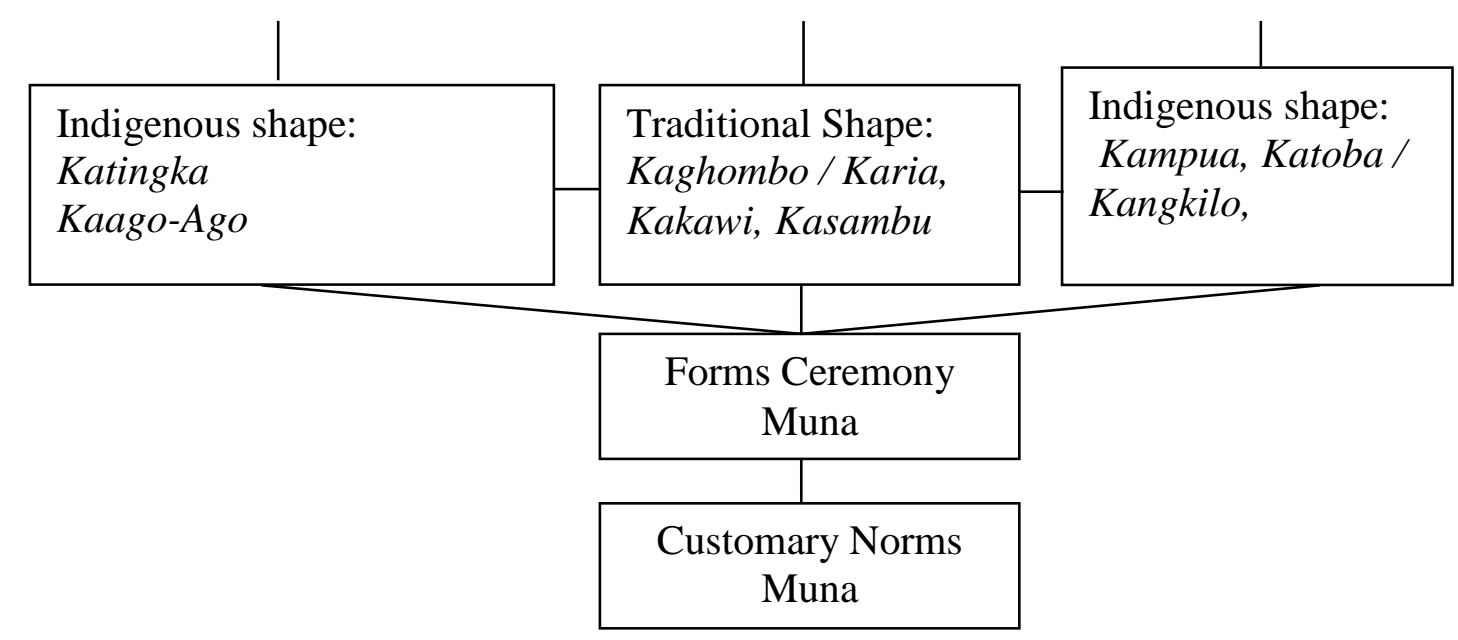

Muna communities that inhabit one of the archipelago islands long ago have had a tradition rooted in life. The tradition of the whole set of conduct from public life in the womb until death. However, growing and experiencing the acculturation tradition has been done since the arrival of Islam in the early fourteenth century AD. So the estuary, Muna society, resulted in three types of traditions: Muna's original tradition, the tradition of acculturation with Islam, and Islamic tradition.

First, Muna's native tradition is a tradition established by Muna society due to the development of civilization. As a limitation that, this tradition had existed before Islam arrived in Muna. Habits are included in the original tradition Muna is kasambu (bribe). Kasambu only applied to the first pregnancy of a woman. While for a second child and so was not given. The procession is carried out when the fetus of a mother aged 7-8 months, or about one month before the birth. Kasambu procession, which both spouses (husband and wife) bribe each other. Once bribe should be eaten or eliminated. If it is not done, the rest is given to children in the vicinity that have been prepared.

Further bribery procession passed by other family members. Second, acculturation tradition is a tradition that is the result of a mix between indigenous traditions Muna with Islamic tradition. At first, Muna society does have a particular tradition. Since Islam entered in Muna blend of both traditions included in the tradition of acculturation is the marriage ceremony. Third, the tradition of Islam is a community tradition Muna sourced from the Qur 'an and the Sunnah of the Prophet Muhammad. That is this tradition previously unknown by 
the public Muna. After Islam flourishes, this teaching was incorporated, which in turn shaped the local Muna tradition. Nevertheless, there are inputs for the implementation of indigenous Muna as a quirk. Included in this tradition are akikah (Kampua), circumcision (pengislaman/kangkilo/katoba), etc.

\section{Katoba}

Katoba comes from the word meaning Toba is regret. Katoba is one of the traditional rituals aimed at children, which contains the command of goodness and badness to implement the ban. $^{9}$ As one of the traditions, katoba used as one of the traditional communication media in society Muna until the present day. This katoba still preserved and handed down through the generations by most people Muna; even in its development, there was no fiery clash of Islamic in Muna.

Hadirman explained that Katoba in Muna comes from the top and the base morpheme ka- Toba. Morpheme ka- in Muna means: (1) Nominalization verb (abstract objects, tools, result), for example in kaghosa word 'power,' kaharo 'broom'; (2) A prefix to the adjective, e.g., sala kawanta' trousers'; (3) Prefix on the verb, for example, nekarato 'He came to a sudden'; (4) By looping the noun: something small, like kawale-wale 'huts, were small'; and (5) The repetition of the word nature: instead, for example, nokapongke-pongke 'He is a little deaf. Toba language in Muna means that (1) repentance, for example, pogauno Toba language 'penance', (2) repentance, a conviction, for instance, notobamo, noangkafimo katangarino imamu 'He had turned back, took the advice imam' (3) does not exist (in the figurative language), (4) tobatkan (a religious ceremony for children aged six years: taught all restrictions and good works by the priest and the family witnessed the invitation), for example in dongkilo anahi, dotobadamo 'after circumcision or circumcision ceremony before repentance). Etymology katoba above, actually katoba the ceremonial 'repentance' it. ${ }^{10}$ As one of the traditional ceremonies, katoba literally can be interpreted as a coronation as a form of traditional ceremonies in Muna Islamic community. It is delivered by the imam (speakers) to the child who wants to grow up with the original content of his teaching as the message of humanity to understand and implement the things that can and can not be done according to

\footnotetext{
${ }^{9}$ Indigenous People interview. Muna: March 7, 2020.

${ }^{10}$ Hadirman, "Figurative Language ...", p. 45.
} 
Millatī, Journal of Islamic Studies and Humanities, Vol. 5, No. 1, June 2020: 81-97

the teachings of Islam as well as indigenous teachings. ${ }^{11}$ Another opinion outlining the origins katoba is stated that katoba etymologically derived from the word Toba absorbed from Arabic, the word Tauba (repentance). In a philosophical view of Muna, there is a claim that minors (roughly ages 7-11 years) cannot yet sort excellent and evil. On this basis katoba tradition becomes a necessity performed on children who will enter adulthood.

\section{Stages Katoba and Its Symbolic Meaning}

Katoba a traditional procession that has stages that must be passed by a child with a sincere heart and full of appreciation. Each stage has a meaning and purpose of each so that children can reach the level katoba as real. A discussion of the ritual katoba line with the arrival of Islam in the island of Muna begins with the arrival of Sheikh Abdul Wahid Muna in 1526 AD. It is associated with the arrangement of the kings Muna. It means that Islam entered Muna since the reign of King VI namely Sugi Manuru (1520-1530). However, it is probable acceptance of Islam by Muna society at that time not too broad in the sense that they are individuals. ${ }^{12}$ This is evidenced by the establishment of the mosque that it is not a place of worship as a congregation. The mosque began to establish during the reign of the king Muna La Posasu to VIII. $^{13}$

Katoba comes from the word 'Toba' that means regret. Katoba is one of the traditional rituals aimed at children, which contains the command goodness and badness to implement the ban. ${ }^{14}$ As one of the traditions, katoba used as one of the traditional communication media in society Muna until the present day. This katoba still preserved and handed down through the generations by most people of Muna; even in its development, there was no fiery clash of Islamic in Muna.

Each stage must be followed by children who participated in katoba. Katoba stages are divided into three major phases, each of the significant stages, followed by small stages. Three major stages are stages of preparation, the core stage, and the closing stages. Here is a picture

\footnotetext{
11 Sarmadan, "Upacara Adat Katoba Pada Masyarakat Muna: Analisis Struktural, Nilai-nilai Kultural, dan Pemanfaatannya dalam Pembelajaran Apresiasi Sastra Lama di Sekolah Menengah Atas", Tesis, (Bandung: Universitas Pendidikan Indonesia, 2013).

${ }^{12}$ Supriyanto, et.al., Sejarah Kebudayaan Islam Sulawesi Tenggara, (Kendari: Regional Office of the Department of Religion of Southeast Sulawesi Province and Muhammadiyah University of Kendari, 2009): p. 130.

${ }^{13}$ Interviews, traditional figure. Muna: March 7, 2020.

14 Indigenous people interview. Muna: March 7, 2020.
} 
katoba stage that must be passed by the child. The following is the chart of the stage of Katoba.

The Stages of Katoba

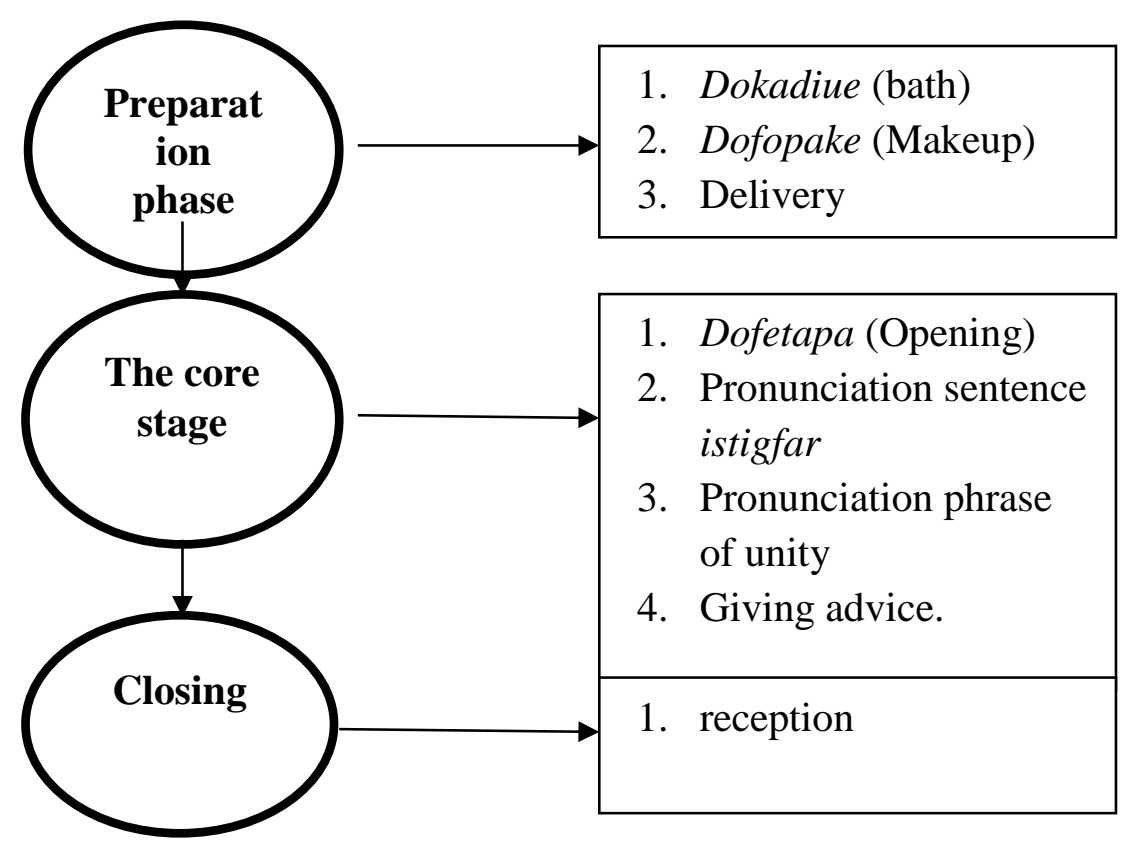

\section{The Katoba Procession Meaning}

\section{The Preparation Phase}

The preparation phase is done before the implementation of the core implemented. This phase includes three aspects: (a) Dokadiue/bathed, the first stage is done by a child who will be "Toba" is bathed. The bathing purpose function removes dirt/grime. This stage is the earliest in the overall procession katoba tradition; (b) Dofopake (Makeup), after dofokadiue (bath), then the next stage is made up is understood as a means to protect the body or the facility to beautify the appearance. However, in addition to fulfilling these two functions, clothes can also act as a non-verbal communication tool for clothing contains symbols that various meanings. Worn clothing is a symbol of identity, identity, honor, and simplicity for someone who can protect from the dangers threatened.

\section{The Core Phase}

The next phase is the core phase. In this phase, the ritual begins with the opening. Participants being "katoba" are sitting cross-legged with a white cloth hold together when participants in groups or more than one person. If the event is only held by individual katoba then the child 
Millatī, Journal of Islamic Studies and Humanities, Vol. 5, No. 1, June 2020: 81-97

will be holding its "katoba." The stage of the second core is reciting istighfar three times. The long process of ritual undertook katoba entirely, the first pronunciation beg forgiveness of Allah so that the heart be clean and be an unforgivable sin. ${ }^{15}$ After the stage sentence pronunciation of istighfar, the next stage is the pronunciation phrase of unity. The table below will explain the words phrase of unity of katoba procession. ${ }^{16}$

\begin{tabular}{|c|c|c|}
\hline Type & Symbol & Meaning \\
\hline & Priest: This kabisaraku angkafi & follow my words \\
\hline & Children: umbe & Yes \\
\hline & Priest: God ASYHADU & I testify that there is no god but \\
\hline & ilaha Ilallah & Allah \\
\hline & Children: God ASYHADU & I testify that there is no god but \\
\hline & ilaha Ilallah & Allah \\
\hline & Priest: $A S Y H A D U$ wa anna & And I testify that Muhammad is \\
\hline & Mubammador Prophet & the messenger of Allah \\
\hline & Children: $A S Y H A D U$ wa & And I testify that Muhammad is \\
\hline & anna Muhammador Prophet & the messenger of Allah \\
\hline \multirow{9}{*}{$\begin{array}{l}\text { Action } \\
\text { symbolic }\end{array}$} & Priest: Asumakusiimo, sakotu- & Verily, I testify there is no god \\
\hline & kotughuno mina bhe Ompu soni & but Allah \\
\hline & somba sapaeno Ompu Allah & \\
\hline & Children:umbe & Yes \\
\hline & Priest: So asumakusïmo tora, & And I testify that Muhammad is \\
\hline & sakotu-kotughuno omputo anabi & the messenger of Allah \\
\hline & Mubammadi kantudu-ntuduno & \\
\hline & Allah & \\
\hline & Children: umbe & Yes \\
\hline
\end{tabular}

Utter two sentences creed implies that we, as human beings, should worship Allah, we have to carry out all his orders and stay away from all prohibitions. We must also recognize

${ }^{15}$ Interview traditional leaders. Muna: March 7, 2020.

16 This table is obtained based on the disclosure of the meaning of the symbols used in the ritual of the priest katoba La Ode Baaru and traditional leaders who understand that La sari katoba ritual. 
that the Prophet Muhammad is the messenger of Allah, the last Prophet. After reciting istighfar and holy 'syahadat', then the next is the process of giving advice. In this process, the priest explains to the katoba participants verbally. In its process, the children should listen to them carefully and also be dofoko umbe (affirmative) any advice delivered by priests. Advising at this stage concerns all aspects of a child's life: 'katoba' teachings of oe sumahano bhe oe pata sumahano (water lawful and water not authorized for use purification). It consists of advice to appreciate parents, brothers, and teachers. It is also to conserve the environment and to be tolerant of other religions, women, and rights.

\section{The Final Phase}

After the initial and the core phases have been done, then the next is the final phase, namely katoba banquet - all participants who attended the katoba event rest and ate food provided. The procession is a venue for community strengthens kinship among Muna community. There a re two types of food served in katoba activities. The first is a unique food located in the gutter (width container for storing food) such as cakes bowsprit, diamonds, katoofino gauntlet (poached eggs), manu kampo (chicken eggs), baruasa, sanggara (fried banana), and rice. The second is 'hidangan' or main dishes explained in detail through pictures and the table below:

\section{Picture of Talang}

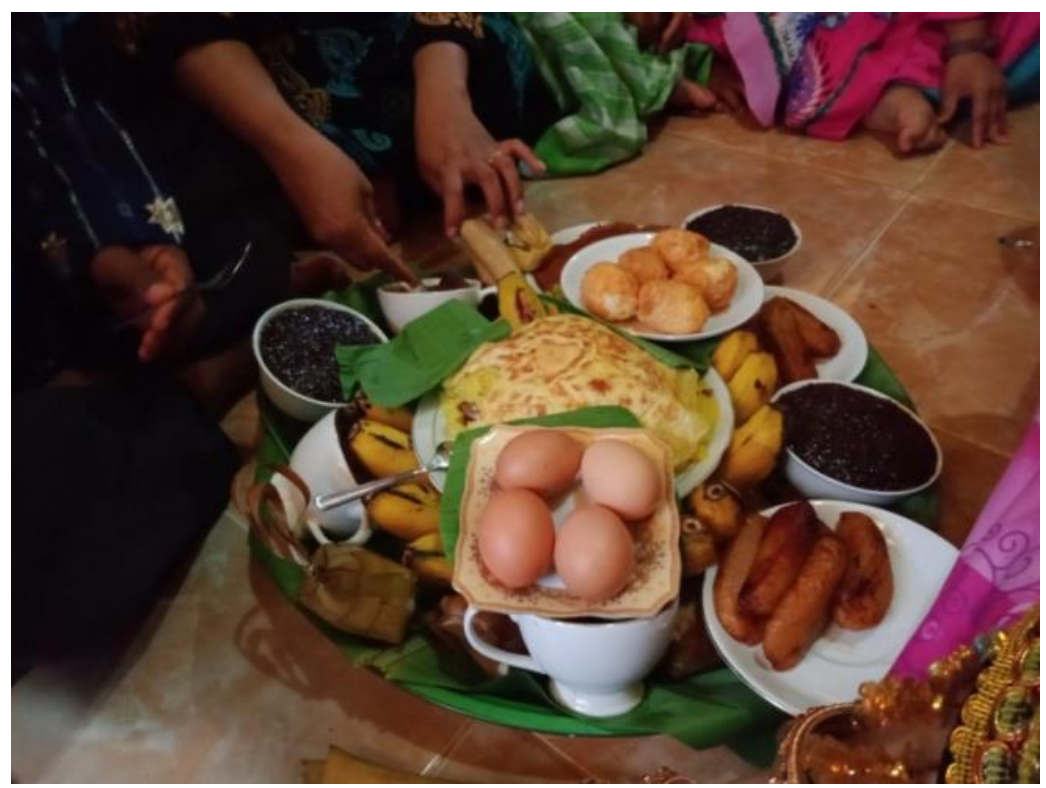




\section{Picture of Hidangan}

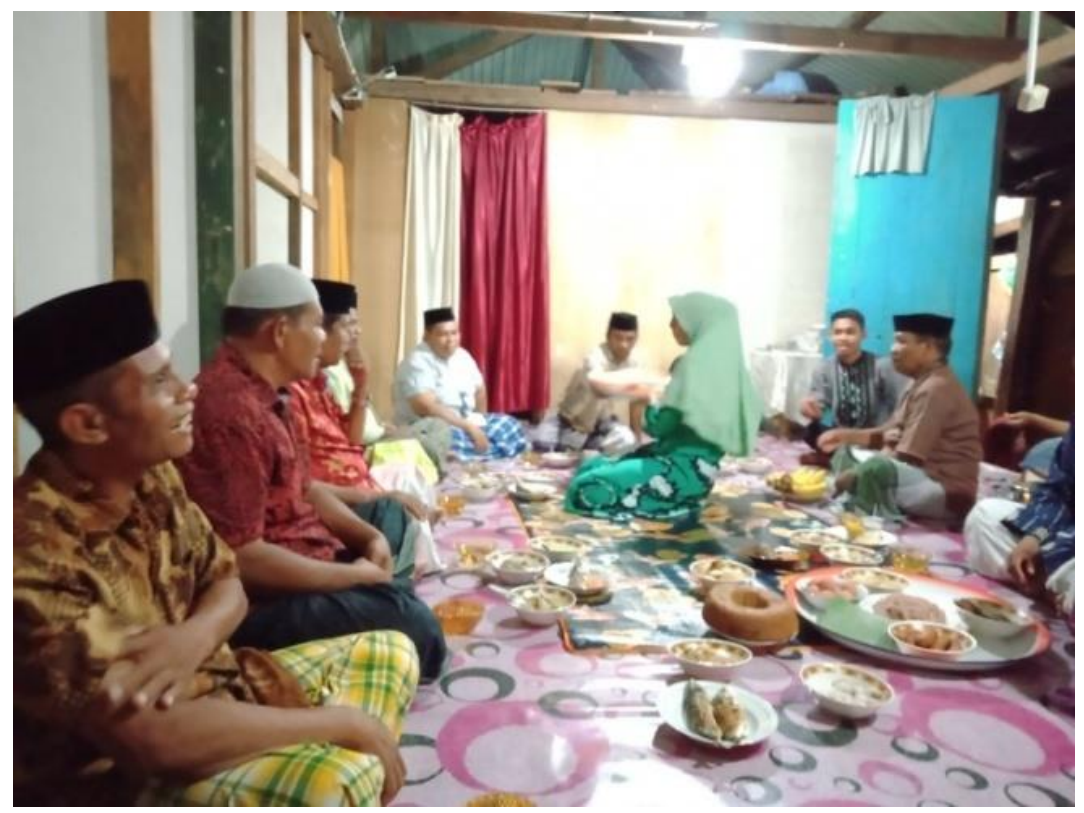

The Meaning of Katoba Food ${ }^{17}$

\begin{tabular}{|c|c|c|}
\hline Type & Symbol & Meaning \\
\hline $\begin{array}{l}\text { Articles } \\
\text { symbolic }\end{array}$ & $\begin{array}{l}\text { Sanggara (fried } \\
\text { plantains) }\end{array}$ & $\begin{array}{l}\text { Symbolizing a man that should always clean the } \\
\text { vital area }\end{array}$ \\
\hline $\begin{array}{l}\text { Articles } \\
\text { symbolic }\end{array}$ & Wadhe & $\begin{array}{l}\text { A kind of snack made from sticky rice by brown } \\
\text { sugar dough. Wadhe red symbolizes human blood } \\
\text { purge of anything unlawful }\end{array}$ \\
\hline $\begin{array}{l}\text { Articles } \\
\text { symbolic }\end{array}$ & Baruasa & $\begin{array}{l}\text { Pastries made of white rice flour dough } \\
\text { symbolizing inner purity }\end{array}$ \\
\hline $\begin{array}{l}\text { Articles } \\
\text { symbolic }\end{array}$ & $\begin{array}{l}\text { Ghunteli manu } \\
\text { kaampo (Chicken } \\
\text { egg) }\end{array}$ & $\begin{array}{l}\text { The egg symbolizes the beginning of human life } \\
\text { are weak }\end{array}$ \\
\hline $\begin{array}{l}\text { Articles } \\
\text { symbolic }\end{array}$ & Lapa-lapa & $\begin{array}{l}\text { Muna is a typical food made of rice and coconut } \\
\text { milk wrapped in a palm leaf symbolizing the vital }\end{array}$ \\
\hline
\end{tabular}

${ }^{17}$ This table is obtained based on the disclosure of the meaning of the symbols used in the ritual of the priest katoba La Ode Baaru and traditional leaders who understand that La sari katoba ritual. 


\begin{tabular}{llllll}
\hline & \multicolumn{5}{c}{ organs of man always hallowed } \\
Articles & Pae pulu (Sticky & Typical rice grown in paddy fields not \\
symbolic & rice) & symbolizing chastity & \\
\hline
\end{tabular}

\section{Problematic Society Against Ritual Muna Katoba}

Previously, Muna society requires every child to perform rituals katoba because it is the only container that aims to prepare children who will enter adulthood mentally. He was given sufficient knowledge of how to treat parents, siblings, and behavior in the environment as a manifestation of traditional teachings. By him, the implementation of katoba ritual is essential and must be implemented by Muna child. However, over time and the social life movement of schools as formal education institutions have much popping both public schools and private schools. School functions as a coaching knowledge, physical, and soul with an explicit curriculum, systematic and sophisticated. According to BPS data Muna number of existing schools in Muna is listed as follows:

\section{Number of Schools in Muna 2016}

\begin{tabular}{lllll}
\hline No. & \multicolumn{1}{c}{ sub-district } & \multicolumn{3}{c}{ Study School } \\
\hline & & SD / MI & SMP / & SMA / MA \\
MTS & \\
& & 11 & 9 & 4 \\
$\mathbf{1}$ & Tongkuno & 6 & 2 & 1 \\
$\mathbf{2}$ & South Tongkuno & 17 & 5 & 2 \\
$\mathbf{3}$ & Parigi & 9 & 3 & 1 \\
$\mathbf{4}$ & Bone & 9 & 4 & 2 \\
$\mathbf{5}$ & Marobo & 18 & 5 & 3 \\
$\mathbf{6}$ & Kabawo & 11 & 4 & 3 \\
$\mathbf{7}$ & Kabangka & 8 & 2 & 2 \\
$\mathbf{8}$ & Kontu Kowuna & 9 & 2 & 2 \\
$\mathbf{9}$ & Naga Kontu & 15 & 4 & 2 \\
$\mathbf{1 0}$ & Watopute & 20 & 9 & 9 \\
\hline $\mathbf{1 1}$ & Katobu & & & \\
\hline
\end{tabular}


Millatī, Journal of Islamic Studies and Humanities, Vol. 5, No. 1, June 2020: 81-97

\begin{tabular}{lllll}
\hline $\mathbf{1 2}$ & Lohia & 17 & 5 & 4 \\
$\mathbf{1 3}$ & Duruka & 12 & 3 & 3 \\
$\mathbf{1 4}$ & Batalaiworu & 14 & 6 & 8 \\
$\mathbf{1 5}$ & Napabalano & 13 & 4 & 7 \\
$\mathbf{1 6}$ & Lasalepa & 10 & 6 & 3 \\
$\mathbf{1 7}$ & Towea & 5 & 4 & 3 \\
$\mathbf{1 8}$ & South Wakorumba & 7 & 2 & 1 \\
$\mathbf{1 9}$ & White sand & 9 & 5 & 1 \\
$\mathbf{2 0}$ & Pasi Kolaga & 6 & 2 & 1 \\
$\mathbf{2 1}$ & Maligano & 5 & 3 & 2 \\
$\mathbf{2 2}$ & Batukara & 6 & 3 & 2 \\
\hline
\end{tabular}

Until 2016, Muna has established various educational institutions on each level. There are 237 primary schools or Islamic elementary schools, 92 junior high / MTS, as well as 66 SMA/MA. It has an impact on the views of most Muna people to the katoba ritual. With the presence of these educational institutions, community Muna then splits into two views according to whether or not a child shall follow the rituals katoba. First, According to this view is the presence of a formal education institution could replace the role of ritual katoba itself. Some parents no longer require children to follow katoba ritual ceremonies. They looked at each school is enough to establish his son to become a better person. Also, the school is useful for fostering their children and leading to a better future. According to the research, ${ }^{18}$ the school's functions are to provide the necessary skills, prepare jobs, provide labor, solve social problems, develop the intelligence of mind and attitude, assist the development of individuals into social beings, conservation, and cultural transmission, etc.

Every child will experience change and development. Schools are seen as the primary weapon in the provision of ethics and morals. Moreover, schools as a complex and systematic institution have a clear and focused curriculum. ${ }^{19}$ One of them is the presence of Islamic education subjects and citizenship education subjects containing religious subjects and the

\footnotetext{
${ }^{18}$ Anwar Hafid, dkk., Konsep Dasar Ilmu Pendidikan, (Bandung: Alfabeta, 2014): p. 51.

${ }^{19}$ Interviews, traditional figure. Muna: February 27, 2020.
} 
norms that apply in society. In Muna, there is a view that does not require children to attend the katoba ritual. Usually, Muna people who come from transtibial marriages, such as her husband, are from Muna, and his wife is from the Non-Muna tribe or vice versa. In Southeast Sulawesi Province, there are various tribes such as the Muna, Buton, Tolaki, and Bugis that transtibial marriages often occur. Besides, in Muna, parents still ask their children to attend the katoba ritual. They argue that the katoba ritual is a very sacred and kaffah event in circumcising their children and cannot be replaced by any educational institution. Katoba is considered a means to knock someone's heart and mind, be honest, responsible, not take the rights of others and themselves to create social harmony, peace of mind, and always have a positive life. In general, such a view is believed by descendants of kaomu (nobility). The katoba ritual still has to be done as a form of cultural preservation and Islamic propaganda efforts.

\section{CONCLUSION}

Based on the discussion and the results of the study, the researchers can conclude the following: 1) Katoba ritual procession broadly implemented in three phases that must be passed by a child with a sincere heart and full of appreciation. Each phase has a meaning and a purpose that children can reach the level katoba as real. First, the preparation phase, which consists of three stages, namely dokadiue (bathed) which means that this stage intends to remove any dirt or grime attached to the child's body, dofopake (makeup), and both of fashion and makeup. Second, the core phase which comprises two stages. Those are dofetapa and reciting istighfar. Dofetapa is an opening in which the children are sitting cross-legged and holding a white sheet. At the same time, the stage of reciting istighfar is intended to beg forgiveness as the preservation of the harmful effects of sin to Allah SWT. However, humans must also accept that life guidance must come from Allah conveyed to His Prophet. Third is the final phase, namely katoba banquet that all participants who attended the katoba event rest and ate food provided. 2) The existence of katoba in Muna tradition is associated with the early arrival of Islam in Muna in 1629-1665 AD, the reign of La Ode Abdul Rahman (title Sangia La Tugho). Since the reign of Sangi La Tugho, the development of katoba tradition is still strong enough because it has been institutionalized in the culture system Muna. Approximately 400 years of katoba ritual journey, a little more influence the dynamics of change in the ritual katoba. These changes occur because of social changes, the changing needs, and the 
Millatī, Journal of Islamic Studies and Humanities, Vol. 5, No. 1, June 2020: 81-97

movement of social systems is always dynamic. The presence of formal educational institutions was able to replace the role of ritual katoba itself. Some parents no longer require children to follow katoba ritual ceremonies. They looked at each school is enough to establish his son to become a better person. Besides, the school is a container that is useful for fostering their children leads to a better future.

\section{REFERENCES}

Abd Syukur, 2010. “Mekanisme Bertahan Kaum Tarekat”. Islamica. Vol. 4, No. 02.

Hafid, Anwar, Dkk, 2014. Konsep Dasar Ilmu Pendidikan. Bandung: Alfabeta.

Hadirman, 2017. "Sejarah dan Bahasa Figuratif dalam Tradisi Katoba pada Masyarakat Muna”. Jurnal AQLAM, IAIN Manado. Vol. 2. No. 01.

Koentjaraningrat, 1992. Beberapa Pokok Antropologi Sosial. Jakarta: DIAN Rakyat.

Littlejohn, Stephan W. dan Foss, Karen A, 2009. Teori Komunikasi. Edisi 9. Translated by Mohammad Yusuf Hamdan. Jakarta: Salemba Humanika.

Lutfi Muh., Malik, 1997. Islam dalam Budaya Muna: Suatu Ikbtiar Menatap Masa Depan. Ujung Pandang: PT Umitoha Ukhuwah Grafika.

Malonda, Alimin, 2011. Nilai Pendidikan dan Nilai Moral dalam Falia pada Masyarakat Muna di Kecamatan Parigi Kabupaten Muna. Kendari: FKIP.

Sarmadan, 2013. "Upacara Adat Katoba Pada Masyarakat Muna: Analisis Struktural, Nilai-nilai Kultural, dan Pemanfaatannya dalam Pembelajaran Apresiasi Sastra Lama di Sekolah Menengah Atas”. Tesis. Bandung: Indonesian Education University.

Sukmadinata, Nana Syaodih. (2003). Metode Penelitian Pendidikan, Yogyakarta: Kurnia Kalam Semesta.

Sugiyono, 2011. Metode Penelitian Kuantitatif Kualitatif dan R\&D. Bandung: Alfabeta.

Supriyanto, dkk., 2009. Sejarah Kebudayaan Islam Sulawesi Tenggara. Kendari: Regional Office of the Department of Religion of Southeast Sulawesi Province and Muhammadiyah University of Kendari. 
Problematic of Katoba Tradition ........ (Aida Hayani and Aris Armeth Daud Al Kahar)

Tamburaka, 2004. Sejarah Sulawesi Tenggara dan 40 Tabun Sultra Membangun. Kendari: Southeast Sulawesi Provincial Government. 